\title{
Game of two Passions: A Football Fan's Autoethnography
}

\author{
Keith D. Parry
}

As an academic studying sport fandom I have found myself in an interesting position. On the one hand I have developed a deeper understanding of sports fans, the ability to explain the nuances that are displayed by the most fanatical of fans, a knowing understanding of the behaviours exhibited; and yet at the same time I would have to confess to being a sports fan and cannot distance myself from this fact. I must admit to engaging in a number of the behaviours I study, and I have found that my deeper understanding of fandom has led me to question myself and the importance that I place upon being a sports fan. Through my academic study I am aware of both the beneficial and detrimental effects that following a sports team can have on an individual (Wann et al, 2001) and have begun to look for signs of these in my own life. This account is a first step at utilising my own understanding and feelings as part of a study into sports fandom and in particular the actual experiences that fans can have. As an academic and also a sports fan I hold a privileged position to be able to shed light on this topic.

Fleming and Fullagar (2007) have highlighted that one way researchers can bring their own experiences to their academic roles in such a way to engage with sports cultures is through the use of autoethnography. Muncey $(2010$, p. 2) states that autoethnography is 'a research approach that privileges the individual...that evokes the imagination of the reader' while Ellis and Bochner (2000 cited Sparkes, 2002, p. 74) define it as 'an autobiographical genre of writing and research that displays multiple layers of consciousness, connecting the personal to the cultural'. Traditional research on sports fans has typically used some form of quantitative measure to identify behaviours which fans exhibit. As such it is then discussed in an objective, deductive manner which is devoid of human feeling or emotion and which will usually have no trace of the researcher's identity (Wall, 2006). And yet being a sports fan is all about emotion and the experience of supporting "your" team. It is something to which people commit time, energy, and, in some sense, their self. Traditional accounts of sports fans rarely reflect the individual experience nor do they give a real sense for what being a sports fan is actually like. Sparkes (2000) called for greater acceptance of approaches which were more emotional and personal, which Wall (2008) highlights as being part of the very nature of autoethnography. In Australia a number of studies have used qualitative methodologies to capture the trials and tribulations of Australian Football League (AFL) fans (Harms and Jobling, 1995; Klugman, 2008; Klugman, 2009) yet this cannot be said for English Association Football. While there are a number of compelling autobiographical accounts of sports fandom (the one I most enjoy is Nick Hornby's account of his devotion for Arsenal Football Club in Fever Pitch - even with the author's devotion to a rival football team) the field of qualitative research appears to be limited when it comes to Association Football fandom. In light of this lack of personal, emotional accounts of association football fandom, I have been drawn to producing an evocative autoethnography in an attempt to give a more vivid picture of what being a football fan can actually be like. 
The account below tells my story of being a fan of Liverpool football club (LFC), detailing the psychological highs and lows that entail following a football team.

\section{Me, myself, and LFC}

For as long as I can remember I have been a football fan and in particular, a fan of Liverpool Football Club. If I am honest I do not know why or when this started, it has always been that way. Whatever the reason I was firmly entrenched as a Liverpool fan by the time lan Rush scored the winning goal in the 1986 FA Cup Final, as although I was not watching the game I recall hearing it on the radio during a family day out and revelling in the team's victory as a six year old. Since that time I have always been recognised as a Liverpool fan by those who know me, at school, University and now in my professional career.

\section{Reflections on June/July 2009}

With the summer here people around me are enjoying the warm weather and looking forward to longer evenings, barbeques, and time spent on the beach. Not me. For me this is a time of pain and suffering. The enforced withdrawal that the end of the football season brings is almost unbearable and requires me to find new ways to satisfy the inner demon which lurks inside my soul. That is how I have come to see my fandom. It is a demonic force which lives inside me, and which controls my life. I hate it yet I am not able to live without it. Every year the sense of emptiness which I feel at the start of the summer cuts deep into my flesh, attacking my mind and body. Weekends seem to be somehow incomplete. On a Saturday I typically get up and watch several football related television shows as I eat breakfast and before I go to play football; after playing I will then sit in a bar watching another light-hearted football results show with my teammates to follow all the goals as they fly in; the day is completed by watching highlights of the important games. My day starts and ends with football - watching football, discussing football, thinking about football. This is rudely interrupted in the summer. These programmes, these comfortable companions, disappear from viewing schedules, disrupting long established and reassuring routines which will be familiar to all serious fans. There is a gulf on Sunday afternoons when I would normally watch the televised game or games which leaves me feeling strangely restless, not knowing what to do. The activities which I do with my family do not replace these, they do not give me the same feeling of excitement. It is not just at the weekend when this loss is felt. Without the almost continuous stream of games to report on or broadcast the media focuses on transfer rumours and stories. This serves as a poor substitute, yet any fix is better than nothing. With no games to watch or results to discuss, I now trawl newspapers and websites scavenging on the transfer rumours which abound at this time of year. Each morning, eating breakfast almost on autopilot, I tune in to Sky Sports News to hear the latest football news - this is the news which really matters; not war, famine and suffering round the world, but player transfers, results and football gossip. I feel my heartbeat increase over news of possible transfers or "done deals". I catch up on any rumours which I was unable to keep abreast of while sleeping. Throughout the day moments are stolen to ensure I know who has been transferred where or even who might be. The endless wait for a new story to break is interminable. Irrelevant, uninteresting 
snippets of (mis)information keep me going. Why does this matter to me so much? Why do I have to know about every club and every player? It is strangely addictive, it is how I define myself; I know about sport and football, and more importantly those who know me, also know that I know.

\section{Extracts from diary August $16^{\text {th }} 2009$}

After a hiatus when time has passed all too slowly the much awaited-for start of the season has finally come! I am preparing to put myself through the emotional rollercoaster all over again. I feel my emotions running higher than usual as our first game of the season is being shown live on television, away to Tottenham (a London team) - I hope we beat them, I really cannot stand Tottenham. The sale of midfield maestro Alonso to Spanish giants Real Madrid has left a sense of unease though. We should not be selling our good players; we should have a team filled with the very best players. Rumours abound surrounding the financial plight of my once-great club which also makes me feel unsettled. The arrival of an expensive Italian replacement does not fill the void and, to make matters worse, he is injured and will not feature until October. I have to admit that I am a bit anxious; our squad seems weaker than last season; when we were not good enough; so how can we hope to compete this year? [Written after the match] Sure enough we have lost. I knew it. I said we would. It is going to be another season of disappointment, shattered dreams, and heartache. I know it is. I just know. My pessimism is not shared by fans of all clubs. I have watched interviews with fans from the three clubs newly promoted to the Premier League, who believe that they will easily stay up, confidence in the face of statistics, finances and squad quality. Who are these fans? What do they know?

\section{Diary entry August $21^{\text {st }} 2009$}

Only days into the season and I have flown away for a few weeks abroad with my wife. I was initially torn between the excitement of going abroad and the worry of missing out on the football season at home. A few days into our trip and I am becoming just a little concerned. We are staying in the smallest village in Sardinia and there is no television and no internet access! Yes the countryside is very nice, yes the food is wonderful but the region is very rural and there are no bars which show "proper" football, no internet access where we stay and certainly no British newspapers. I had been so certain that some of the places we stayed would show games on television or at least have access to the internet. The Premier League is supposedly the biggest and most watched league in the world so how can it not be shown on television - what else do people watch on television? I don't know what to do now - I need to stay involved some way or other with the new season. I have found my mind wandering, I think about how I might be able to find out the scores and watch games. On a number of days I have found a brief solution, Italian newspapers have the Premier League table yet this has only made the loss more apparent. The table is meaningless, I still do not know who is playing well, who is scoring goals, how the season is going. These are the things which matter to me. I have to know these things. I have to know everything there is to know about football. I am surprised by how much I am missing football, how hard it is to go without, just how important it has become in my life. 


\section{Reflections - August $22^{\text {nd }}-25^{\text {th }} 2009$}

I look back on recent events when football has impacted on my life and I am startled. I recall times when a single result, sometimes not even when Liverpool were playing, has ruined my day and even my weekend. Times when a goal being scored has left me moody and upset, lashing out at those around me; unable to provide a suitable justification for my ill tempter. They would not understand why I am so upset. To them it is just a game. There seem to be more disappointments and bad moods than there are elations and good moods. Even good results often come at the end of a rollercoaster match with extraordinary highs and excruciating lows. I am starting to wonder if my level of involvement is healthy. Mood swings based on results, outbursts of temper, loathing for fans of rival teams; is this good for me? Is this what it feels is like when you are trying to cope with an addiction. Am I addicted to football? The realisation that I may be hits me with the force of a blow. The scales fall from my eyes and I reflect on what is most important in my life and decide it should not be football. As the days pass slowly, oh how slowly, I try to steel my resolve, to convince myself that I can survive without football. Sometimes I think I am succeeding, I think I can function like a "normal" person and do not need to know the scores or watch games. I think I can manage to live life without being a sports fanatic.

\section{Extract from diary August $25^{\text {th }} 2009$}

My parents have texted me scores from the Ashes Test Matches and this tantalising glimpse into the sporting world back in the UK has started my mind racing, spinning to thoughts of football back home. I am sorely tempted to text back and ask for the football scores as well. The spectre of becoming a football addict stalks me, a voice calling me to text, to give in. My vision of a life without a reliance on football stops me. I have seen a tantalising glimpse of another world and I dearly want to be a part of it. And one text would not be enough; the reply would not give me enough information, I need more. No! I am determined not to give in. Maybe I am starting to get withdrawal symptoms? I find myself short tempered and distracted. I am unable to fully enjoy this culture I am immersed in. It is almost as though I am having mental "shakes," my mind fighting a battle to control the urges inside. I do not need to know the scores, I do not, it does not really matter. Being in the middle of the countryside in a foreign country helps slightly. There is no one to talk to about the games, no fellow fans that can ignite my passions and lead me back down the path to temptation. It is too shameful to admit to my wife why I appear distracted, why I am short-tempered at times. Shameful to explain that her caring concern is thrown back because I am missing football on television. She is not a football fan so I cannot share my burden; I am forced to face the long narrow road to recovery on my own. I will just keep it all bottled up inside.

\section{Diary entry September $1^{\text {st }} 2009$}

We have moved location for a couple of days and our hotel has wireless internet access! Temptation has come roaring back into my mind. I can now find out what has been going on, get in touch with the real world. Still I resist. 


\section{September $2^{\text {nd }} 2009$}

I had not given in; then a need arises to check the internet for flight details and I watch helplessly as my web browser opens to my homepage with sports headlines emblazoned across it with sensational stories. I cannot stop myself, I no longer control my limbs; all it takes is one simple click of a mouse button and I feel myself falling, tumbling down into the yawning chasm which is my addiction. I gorge myself; I have lost all track of time; it started with just checking the league tables but then it was the results, then it was the scorers, then the match reports. And it is not just one league, it is all of them, Premier League, Championship, League One, League Two, Scottish Premier League, La Liga in Spain, Italy's Serie A, the list goes on. I need to know the results, who has been playing in teams, who has scored goals, what the fans and press are saying. There is no end to it, I find myself glued to meaningless results in leagues which I have no vested interest in. Except I do have a vested interest! I want to know how every team is doing. How players that I like are doing, how players that I don't like are doing. If I do not know these results then I am somehow less of a fan. If I do not know everything about football what does that say about me as a man? Am I less complete? At times I am vaguely aware of my wife being present, she wants to go out for dinner, she is asking if I am ready I think...I am not sure what she is saying, I am lost in another world, I am not paying attention. Finally I return to consciousness and am aware of the other world around me, aware of how late it is and of the need to release my hold on football. Reluctantly I log off. I feel exhausted; drained from the intensity of reliving every result and performance. The highs and lows of games which I have not witnessed but which I have experienced in my mind. I feel ashamed, dirty, weak. I have given in and loath myself for it. Why did I do it? I despise my own wretchedness.

\section{September $3^{\text {rd }}-9^{\text {th }} 2009$}

As days pass we now have more frequent access to the internet in our hotel and I am able to stay abreast of the games going on. I feel different. The need appears to have receded somewhat. The initial desperation I was feeling has retreated. I still find myself thinking about football at odd moments but it is not as frenzied as it was before. Being away from games and not being able to watch or talk about them has left me somehow detached from it. It is an odd feeling, I feel like I am missing something. At the same time I find I am enjoying our time away more, I think I am in a better mood at least.

\section{September $10^{\text {th }}-21^{\text {st }} 2009$}

Back in England and I feel I am not as desperate to watch football as I thought I would be. On "Super Sunday" I flick on to the start of a game but then I am happy to go out with my wife. When we come back in the game is on yet I do not feel the same need as before and I only turn over to see the score rather than watching every minute of the game. Since we have come back the addiction does not feel quite as powerful. I have a new sense of freedom; I do not need to plan my days around viewing football; I have been able to switch the television off when a match is on. Despite having "fallen off the wagon" on holiday I do 
feel that I am growing stronger, coping better with these desires. However, although now it feels as though I am recovering from this disease which has plagued me for too long, I am sure I am not cured; I know that I could easily be drawn back in and find myself glued to the television once again. It is one day and one-step at a time. Little successes make me feel proud. I have not signed up to the ESPN satellite channel that is showing even more live Football. I want to, the lure of extra Premier League games, Major League Baseball, US sports, is strong, yet I have resisted. I have refused to join in a fantasy football league with my teammates and the sense of relief from this is liberating. These fantasy games exists as a way for sports fans to display our knowledge and understanding of the game, to prove that I know more than those around me and could do better than the real mangers of teams. I had to prove this to everyone, prove how much I knew to the world around me. I would studiously examine lists of players at the start of a season, looking for those who will score me points through their performances over the season; a bargain buy who will tip the balance of success in my favour. These fantasy games add to the pain and suffering which I endure over a season as now previously meaningless matches acquire significance as the wrong results will not only cost my fantasy team points but will also lose me face with my peers. Now, it is not just the result of "my" team which matters. Now, it is not just one result which has the power to ruin days and weekends. One of my teammates moans "I can't believe Drogba is injured, it's bad for my fantasy football team". I smile knowingly; last year I would either have been sharing his pain if I had the player in my team or revelling in his misfortune if I did not. Now I almost sympathise with the poor soul, I know what it is like to be there, I must look very smug and self-satisfied.

\section{Diary entry September $26^{\text {th }} 2009$}

Today is a big day; a big test of how far I have come. For the first time in maybe nine years I am going to Anfield to watch a Liverpool game. My family has bought me tickets to see Liverpool play as a birthday present. I am unsure how I will feel, how this will help/hinder my "recovery." As I sit in our hotel writing this I wonder if the addiction will take hold of me again or if I will be strong enough to face the beast, to stare right into the jaws of my drug and to turn my back on it. Will the excitement of standing in front of the Shankly Gates be too much for me? Will the noise of the crowd pull me in? Already I feel I have slipped. I have come to Liverpool with my scarf; I want to visit the club store; I need to buy a programme. There are many rituals which I associate with coming to watch games here which I want to recreate. I can feel my stomach starting to churn as the day drags slowly towards kick off time.

\section{September $26^{\text {th }} 20091: 30 \mathrm{pm}$}

We take a taxi to the ground. Arriving by taxi rather than walking diminishes the experience slightly as normally there was a build up of fans as we got nearer to the ground. Normally I can slowly feel my excitement rise. There is normally a crescendo of red as the stadium nears. Now we are dropped into the middle of this kaleidoscope, a broiling mass of colour and noise. We had passed a growing number of fans as we approached the stadium but as we step out of the taxi I am suddenly hit with the full matchday experience. Memories of my childhood come back, vendors at the side of the road hawking their wares with cries of "Buy 
your scarves, badges here", the familiar sounds, and the smells. The roads are packed with fans sporting their team identity. I realise that I have left my scarf in the hotel and I feel as though I am missing a part of my costume. Will others notice that I am missing a vital ingredient of my fan identity? Will I stand out from all the others? The stadium rising, towering above the terrace houses which crowd around it. The throng of people washing around the stadium like waves, breaking around the Police horses which watch over the fans. Despite my desire to retain my calm demeanour in front of my wife, I feel I am losing the battle. I realise that I am missing bits of the conversation which is directed at me, I am too busy enjoying the wider atmosphere and experience. I stare around with child-like glee, a smile plastered across my face, my senses reacquainting themselves with once-familiar sights, sounds, smells.

\section{2:30pm}

Through the turnstile and up a dark flight of stairs, finally emerging into bright light, the pitch opening before us with the stands soaring over it. There is no dark in my soul now, now I am basking in the light and glow of this place. I feel a sense of... I am not sure what...awe perhaps. This is a place which was a part of my younger years. Red and white dominate; shirts, scarves, flags. The scene in front of me is a flowing patchwork of colour. Vast flags commemorating the club's achievements and legends are passed above the heads of fans; an immeasurable billowing sail to awe and intimidate the opposing fans and players. I love the colours, love the passion which is displayed towards this team. The noise steadily increases as kick off nears, the excitement building. I am sure that I am staring around me with almost child-like glee. I am remembering where I stood at certain games, how the crowd used to surge forward when a goal was scored, the songs honouring my favourite players. As 3pm draws near a ritual begins which sears my soul and sends shivers down my back; the public address system blares the first line "When you walk..." of You'll Never Walk Alone, Gerry and The Pacemakers' iconic tune which plays such a big role in this club. Within a word or two the recording is drowned out around us as the crowd join in. Fans stand with arms above their heads holding their scarves while swaying and singing, looks of euphoria on their faces. I again feel inadequate as I am lacking a scarf, I cannot fully engage in this ritual yet I still join in the singing, savouring the moment. As the song ends I join in those around me in applauding our collective efforts. I am lost in the experience, I am no longer aware of my wife alongside me, my inhibitions slide away and all I can think of is the pure joy I feel to be standing, arms aloft, singing my pride for this club.

The crowd expectantly urge the team on; we cheer, shout, clap, and plead for them to perform for us. The expectation is heightened by the perceived inferiority of today's opponents. This is a game we have to win! Since my last visit many of the players have arrived at the club and I do not know the words I am meant to be using to worship them. I feel inadequate and nervous; what if someone notices that I am not joining in with the songs? Will they question my support? Will I be accused of not being a "real" fan? Memories of being confronted by a drunken middle ages fan with these accusations when I was younger return to haunt me. I feel uncomfortable in a surrounding which before was so familiar. I am nervous, I feel almost unclothed. Suddenly the ball is in the goal. It is hard to 
describe the emotions and actions which follow this. All feelings of inadequacy and discomfort are banished in that one moment. Suddenly all I feel is immense pleasure, shared with those around me. A roar erupts, a primeval scream, a noise which explodes from somewhere deep inside. Arms are thrown wildly in the air, grown men jump and career, hugging friends and strangers alike. A look of shock and panic spreads across my wife's face as the fans around her try to share their joy with her. The sense of relief which I feel is palpably shared by those around me now. Wait! Poor early season form has left the players feeling nervous and the opposition now press forward. I feel I know what will happen; I have seen the underdogs spoil the show so many times before. Goal! The pocket of away fans now explode in jubilation. The home fans release cries of anguish, howls of anger and frustration. I feel disgust at my team for having allowed this to happen, I hate the opposition for spoiling my day; I feel an ache in my stomach. The game continues and the frustration grows. The sky seems to have darkened, despair sits heavy over me. Then, charging forward, a modern knight in shining armour, a player is through again. All is not lost perhaps, he will rescue the day. The net ripples once more and the crowd again explode. Arms raised skywards once more, people jumping, hugging and cheering.

\section{4:02pm Second Half}

With Liverpool attacking the goal behind which we are sat I can almost feel those around me trying to suck the ball into the net, willing it in. It is not long before our collective lung-power has the desired effect and a third goal goes in. The crowd are ebullient; they do not believe there is a threat now. The nervous energy dissipates and collectively we begin to relax and anticipate more goals for our team, the pent up anger and aggression are forgotten...at least for today. My nerves have gone, the result is safe, and I can bask in the victory. You'll Never Walk Alone reverberates around the stadium once more; the crowd are happy and keen to proclaim their faith and sense of belonging. Further goals add to my joy, the cheers now are less passionate and more mocking of our opponent's inabilities and misfortunes. All around scarves are in the air, fans displaying their affiliation, holding their colours aloft waving them. I feel myself surfing the wave of support around me, carried high on the collective passion for the team.

\section{4:49pm}

At the final whistle one last cheer celebrates the victory. Applause greets the players as they stroll around the pitch to acknowledge the contribution of the crowd, and to congratulate each other. Slowly the stadium begins to empty. We are among the last to leave, I watch the throng funnel down the exits as we await our turn. As we pass out I take one last glance at the stands and pitch, savouring the image and atmosphere, not knowing when I will return. Outside there is a communal feeling of satisfaction, a warm contentment is wafting through the air. Happily we chatter, dissecting the performance and the implications of this and other results. It feels good to have been part of the victory, to know that I played my part in it. As we leave I am tempted by the myriad of merchandise on offer from independent traders outside the ground. Now the result is safe I am tempted to proclaim my loyalty to the club, to link myself through an outwards display of colour. I want to be seen as part of this 
success. The pull of the club returns. Despite my will to regain control over my emotions and feelings I have been seduced by the excitement and enjoyment of being part of the success.

\section{Diary entry $27^{\text {th }}$ September 2009}

I am writing this sat on the train travelling back home. I feel uncomfortable, unsettled. I am concerned that I cannot escape this addiction. For all my good intentions, my supposedly firm resolve, I feel no better off now that I was a few months ago. I am still addicted to this sport. I had thought that I could control this, I would be able to disengage myself from football and lead a normal life. Perhaps the level of addiction has lessened, yet I do not feel it will ever leave me. It will always be a shadow lurking, a ghost on the edge of my vision. Perhaps I should endeavour to seek help from a professional, to lay myself down on a soothing couch and admit my weaknesses to a psychotherapist. Alternatively, to join in a support group where I will stand up in front of other addicts and declare, "My name is...I am a sports fan." Perhaps I should embrace it. Give myself in and allow this addiction to define who I am and what I do, as so many others do. I want to fight it. I want to beat it. I do not know if I can.

\section{A game of two passions?}

Having taken stock of my thoughts, hopes, and fears I have realised how passionate I am about football. It has become clear to me how highly I value my football fan identify and the importance which I have placed upon it within my life. But whether this passion for football is too dominant in my life is something I have been trying to resolve. I am not alone in describing my fandom as a passion. Klugman (2006; 2008; 2009) frequently refers to the passion of AFL fans and eloquently details experiences of pain, grief and suffering that are entwined with the love of a club. While the topic of passion and sports fans is one which has only recently been examined, the role of passion in sports performance has been examined in a number of settings (Vallerand et al, 2006; Vallerand and Miquelon, 2007; Vallerand et al, 2008b). Vallerand et al (2008a) utilised a series of three studies on football fans and found that the Dualistic Model of Passion (Vallerand et al, 2003) was applicable to a sports fan setting. Defining passion as "a strong inclination towards an activity that people like, that they find important, and in which they invest time and energy" they go on to say that "it has to be significant in their lives, something that they like, and something at which they spend time on a regular basis" (ibid, p. 757). The idea of passion as discussed by Vallerand and his colleagues resonates with my own feeling and emotions towards football. Football is clearly something which is important to me and which I, on a regular basis, spend (too much?) time on. Through the course of this autoethnography I have come to realise the significance which I have placed upon football and being seen as a football fan. Although, through reflection on my feelings and thoughts, it is perhaps not always something which I like, and which has at times caused me pain and anguish, as was found by Klugman in his studies (2006; 2009). However, this apparent juxtaposition is not uncommon and Vallerand et al (2003, p. 756) highlight that being passionate about something should lead to feeling pain in this manner. The etymology of the word passion derives from the Latin passio which 
was used to refer to suffering or enduring and, in Christian theology, is often used to refer to the sufferings of Christ. This original meaning of the word conjures exactly the same kinds of mixed emotions which I have felt and documented. Another key aspect to understanding passion is that the activity being engaged in will also have become internalised into one's identity in such a way that some aspects of the activity come to represent central features of the individual's identity (Vallerand et al, 2008b). Through my apparent need for others to see me as knowledgeable of football and as a football fan I have clearly internalised this. At various points in my account I stress the need to be seen this way:

I know about sport and football, and more importantly those who know me, also know that I know. June/July 2009;

I had to prove this to everyone, prove how much I knew to the world around me. September $10^{\text {th }}-21^{\text {st }} 2009$.

Yet the Dualistic Model of Passion distinguishes two kinds of passion, Obsessive Passion, referred to as an uncontrollable urge to engage with the activity that the individual loves, and Harmonious Passion where there is again a strong inclination to engage in the activity however this is done willingly and with a sense of volition (Vallerand et al, 2008a). Vallerand et al (2006) believe that obsessive passion in effect controls the individual and will result in them feeling an uncontrollable urge to engage in the activity which can lead to negative consequences and emotions. These emotions may be feelings of distress with oneself whilst engaging in the activity, negative effects and feelings such as anger when prevented from engaging in the activity, or conflicts in other areas of the individual's personal life (Vallerand et al, 2003). At numerous points these conflicts of emotions and the sense that I have not been able to control my actions and thoughts echo in my diary and reflections. Being a sports fan is clearly causing areas of conflict with my personal life to the extent that I have not been able to fully experience the pleasure of non-football activities and even causing me turmoil and pain when engaging in my beloved activity. Vallerand et al (2008a, p. 1290) further state that fans who experience obsessive passion "experience lower life satisfaction, self-esteem, and positive affect (except for the emotion of pride) than harmonious passion" - having recognised myself as an obsessively passionate football fan do I now have to accept these negative flaws in my character? The behaviours which I exhibit are not uncommon amongst sports fans and are not even that extreme (while these behaviours are not explored here discussions of these are available in numerous sources, see for example Wann and Branscombe, 1993; Wann, 2002; Campbell et al, 2003; Kwon et al, 2008) and as a result many more individuals will surely be living lives as obsessively passionate sports fans, displaying feelings of hate towards rival fans, conflict in their love life, and, if the link between passion and team identification is made, then possibly acts of violence (Wann et al, 2001). The realisation of this conflict has however dawned on me and my account appears to show an attempt to move from this state of obsession to one of harmony. At times my account appears to reveal a longing to be in the situation where my passion is of importance to me but is not the overwhelming element of my identity, where being a football fan is in harmony with other areas of my life (Vallerand et al, 2008a). Yet it is worth considering if Obsessive Passion is truly detrimental and whether distancing oneself from the object of one's passion diminishes the relationship to some degree? Harmonious Passion involves a degree of control over emotions that may negate the ability to embrace the object of desire and to become lost in it. For many, one of the attractions of sports fandom is that it allows individuals to escape from the realities of their everyday lives (Wann, 
1995). A move away from Obsessive Passion is likely to diminish the levels of suffering and grief that sports fans will experience and yet being a fanatic is not a rational experience, sports fans return to watch bad performances and defeats on a regular basis and will relive the moments of their greatest pain and suffering (Klugman, 2008). Sports fans even take pride from standing by their team when they are not doing well and can identify even more strongly with a losing team (Campbell et al, 2004). In some way it may be that moving away from Obsessive Passion would actually diminish the enjoyment of being a fanatic.

\section{Further Investigation}

Throughout my account I have noticed a number of instances where I have referred to my fandom as an "addiction". It is not possible to provide here a full discussion as to whether sports fandom can be classed alongside more commonly recognised addictive substances or behaviours such as gambling, alcohol, or drugs. However the phenomena of exercise addiction is now widely recognised, even if insufficiently studied, and in their discussion of this Krivoschekov and Lushnikov $(2011,509)$ define addictive behaviour as

an attempt to escape real life by means of artificial changing one's own psychical state by taking drugs or performing certain activities.

Based on the account and discussion above and considering the number of people who regularly attend sporting matches and events, I believe that there is need for greater exploration of the extent to which some sports fans obsess over their team and whether this should warrant a similar level of consideration as exercise addiction.

\section{The use of autoethnographical methods to sports fan research}

Fans (or fanatics) have been described as:

someone extreme, who lies outside the normal range of behavior (sic) in his or her devotion to a cause, religion, a team, or even a brand [who can be] vilified, ridiculed, or championed, depending on one's perspective (Smith et al, 2007, p. 78).

Smith et al (2007) additionally highlight that fans have traditionally been studied from a thirdperson perspective and this is particularly true for sports fans. Research on sports fandom typically utilises an empirical examination of the behaviours of sports fans as a group or of particular groups (Campbell et al, 2004; Kwon et al, 2008; Madrigal and Chen, 2008; Theodorakis and Wann, 2008). This approach does not allow the lived experiences of sports fans to be examined in depth and hence does nothing to counter the view that sports fans are somehow abnormal. Through the use of more emotional and personal accounts such as autoethnography it should be possible for readers to develop a greater understanding of and insight into sports fans. Similar methods have been utilised in areas of sports research, most commonly to examine the role of the body itself or in those areas allied to health care, (Allen Collinson, 2005; Zanker and Gard, 2008; Stone, 2009; Drummond, 2010) though sport fandom research has been slow to embrace this methodology. Norman Denzin (2006) highlights that academics have struggled with writing themselves into their research and it appears that sports fandom researchers are not alone 
in their timidity. As Sarah Wall (2008) has discussed it has been no simple task to produce this autoethnography and I have similarly faced the anxieties, over academic acceptance of the method and exposure of myself, that others discuss (Muncey, 2005; Wall, 2008). I believe that this approach has benefit to not only academics studying sport fandom but also to academics in other disciplines, and to the wider population as it will allow a greater understanding of the experiences of sports fans. As stated earlier it is my hope that this account carries a degree of authenticity which rings true with readers and will provide an insight into some of the highs and lows which go with being a sports fan. I believe that through academics studying sports fandom embracing methods such as autoethnography, and by writing themselves into their research, the view of sports fans as being abnormal may be challenged. At the very least it may highlight the impact that this devotion can have on the lives of individuals. In this manner it may serve the purpose of making a (small) difference in the world or may "change people" which Ellis and Bochner (2006) believe autoethnography is able to do. 


\section{References}

Allen Collinson, J., (2005). "Emotions, interaction and the injured Sporting body", International Review for the Sociology of Sport, Vol. 40, No. 2, pp. 221-240.

Campbell, R.M., Jnr, Aiken, D., and Kent, A., (2004). "Beyond BIRGing and CORFing: Continuing the Exploration of Fan Behavior", Sport Marketing Quarterly, Vol. 13, No. 2, pp. 151-157.

Denzin, N.K., (2006). "Analytic Autoethnography, or Déjà Vu all Over Again". Journal of Contemporary Ethnography, Vol. 35, No. 4, pp. 419-428.

Drummond, M., (2010). "The Natural: An Autoethnography of a Masculinized Body in Sport". Men and Masculinities, Vol. 12, No. 3, pp. 374-389.

Ellis, C.S. and Bochner, A.P., (2006). "Analyzing Analytic Autoethnography: An Autopsy". Journal of Contemporary Ethnography, Vol. 35, No. 4, pp. 429-449.

Fleming, C., and Fullagar, S., (2007). "Reflexive methodologies: an autoethnography of the gendered performance of sport/management". Annals of Leisure Research, Vol. 10, No. 3-4, pp. 238-256.

Harms, J., and Jobling, I., (1995). "Australian Rules Football: Saturday Afternoon Poetry". Journal of Australian Studies, Vol. 19, No. 46, pp. 77-88.

Hornby, N., (1992). Fever pitch. London: Victor Golan.

Krivoschekov, S. \& Lushnikov, O. (2011). "Psychophysiology of sports addictions (exercise addiction)". Human Physiology, Vol. 37, No. 4, pp. 509-513.

Kwon, H., Trail, G., \& Donghun, L., (2008). "The Effects of Vicarious Achievement and Team Identification on BIRGing and CORFing". Sport Marketing Quarterly, Vol. 17, No. 4, pp. 209-217

Klugman, Matthew (2006) "Emotional Devotees: Approaching the Inner World of Australian Rules Football Fans". Nicholson, M., Hess, R. And Stewart, B. (Eds), Football Fever: Moving the Goalposts. Maribyrnong Press, pp. 207-222.

Klugman, M. (2008). "Each time I'm reminded of it, I feel as though I need therapy. Australian Football, Tragedies and the Question of Catharsis". Traffic: An Interdisciplinary Graduate Journal, Vol. 10, 97-121.

Klugman, M. (2009). "Loves, Suffering and Identification: the Passions of Australian Football League Fans". The International Journal of the History of Sport. Vol. 26, No. 1, pp. 21-44.

Madrigal, R. and Chen, J., (2008). "Moderating and Mediating Effects of Team Identification in Regard to Causal Attributions and Summary Judgments Following a Game Outcome". Journal of Sport Management, Vol. 22, No. 6, pp. 717-733.

Muncey, T., (2005). Doing Autoethnography. International Journal of Qualitative Methods, Vol. 4, No. 1, pp. 1-12.

Muncey, T., (2010). Creating Autoethnographies. London: Sage.

Smith, S., Fisher, D., Cole, S. J., (2007). "The Lived Meanings of Fanaticism: Understanding the Complex Role of Labels and Categories in Defining the Self in Consumer Culture". Consumption, Markets and Culture. Vol. 10, No. 2, pp. 77-94.

Sparkes, A.C., (2002). Telling Tales in Sport and Physical Activity: A Qualitative Journey. Leeds: Human Kinetics.

Sparkes, A.C., (2000). "Autoethnography and Narratives of Self: Reflections on Criteria in Action". Sociology of Sport Journal. Vol. 17, No. 1, pp. 21-43.

Stone, B., (2009). "Running Man". Qualitative Research in Sport and Exercise, Vol. 1, No. 1, pp. 67-71. 
Theodorakis, N.D. and Wann, D.L., (2008). "An examination of sport fandom in Greece: influences, interests and behaviours". International Journal of Sport Management and Marketing, Vol. 4, No. 4, pp. 356-374.

Vallerand, R.J., Mageau, G.A., Koestner, R., Ratelle, C., Léonard, M., and Gagné, M., (2003). "Les Passions de l'Âme: On obsessive and harmonious passion". Journal of Personality and Social Psychology, Vol. 85, No. 4, pp. 756-767.

Vallerand, R.J., Rosseau, F.L., Grouzet, F.M.E., Dumais, A., Grenier, S., and Blanchard, C.M., (2006). "Passion in Sport: A Look at Determinants and Affective Experiences". Journal of Sport and Exercise Psychology. Vol. 28, No. 4, pp. 454-478.

Vallerand, R.J., \& Miquelon, P., (2007). "Passion for sport in athletes". D. Lavallee \& S. Jowett (Eds.), Social psychology in sport. Champaign, IL: Human Kinetics, pp. 249-263.

Vallerand, R.J., Ntoumanis, N., Philippe, F.L., Lavigne, G.L., Carbonneau, N., Bonneville, A., Lagace-Labonte, C., and Maliha, G., (2008a). "On passion and sports fans: A look at football. Journal of Sports Sciences". Vol. 26, No. 12, pp. 1279-1293.

Vallerand, R.J., Mageau, G.A., Elliot, A.J., Dumais, A., Demers, M-A., and Rosseau, F., (2008b). "Passion and performance attainment in sport". Psychology of Sport and Exercise. Vol. 9, No. 3, pp. 373-392.

Wall, S., (2006). "An Autoethnography on Learning about Autoethnography". International Journal of Qualitative Methods 5 (2), Article 9. Retrieved [10.01.2010] from http://www.ualberta.ca/ ijgm/backissues/5 2/pdf/wall.pdf

Wall, S., (2008). "Easier Said than Done: Writing an Autoethnography". International Journal of Qualitative Methods. Vol. 7, No. 1, pp. 38-52.

Wann, D.L., (1995). "Preliminary validation of the sports fan motivation scale". Journal of Sport \& Social Issues (November), pp. 337-396.

Wann, D. L., (2002). "Preliminary validation of a measure for assessing identification as a sport fan: The Sport Fandom Questionnaire". International Journal of Sport Management, Vol. 3, 103-115.

Wann, D. L., and Branscombe, N. R., (1993). "Sports fans: Measuring degree of identification with their team". International Journal of Sport Psychology, Vol. 24, pp. 1-17.

Wann, D.L., M.J. Melnick, G.W. Russell, and D.G. Pease, (2001). Sports Fans: The Psychology and Social Impact of Spectators. London: Routledge.

Zanker, C., and Gard, M., (2008). "Fatness, Fitness, and the Moral Universe of Sport and Physical Activity". Sociology of Sport Journal, Vol, 25, No. 1, pp. 48-65. 